\title{
自動演奏ベルの振動音響特性に関する研究*
}

\author{
上野大司 ${ }^{* 1}$ ，太田和秀 ${ }^{* 2}$, 松尾有里子 ${ }^{* 3}$, 鄭光澤 ${ }^{* 4}$
}

\section{Vibratory and Acoustic Characteristics of Automatically Performing Bell}

\author{
Daishi UENO*1 ${ }^{*}$, Kazuhide OHTA, Yuriko MATSUO and Guangze ZHENG \\ ${ }^{* 1}$ Mitsubishi Heavy Industries, 16-5 Konan 2-Chome, Minato-ku, Tokyo Japan
}

\begin{abstract}
An automatically performing bell system, which informed the specified time with music, has many types of bell configuration and arrangement. The first requirement for the bell system is to tune the fundamental resonance frequencies of each bell to an equal temperament of scale. Finite Element Method (FEM) was used to determine the natural frequency of the bell and the effect of bell profile such as thickness and diameter on the natural frequencies was analyzed. Experimental evaluation was also carried out to examine the natural frequencies and mode shapes of the similar profile bell series and constant thickness bell series. The tuning algorithm of the fundamental and higher mode frequencies by changing the inner profile of the bell to improve the sound quality was developed using FEM successive calculation and its availability was discussed. Moreover, the acoustic radiation properties of the vibrating bell were examined by use of the Boundary Element Method.
\end{abstract}

Key Words : Music Bell, Finite Element Method, Frequency Tuning, Structural Modification

\section{1. はじめに}

日本の社会が豊かになるにつれて「や寸らぎ」や「豊かさ」を求めるための社会環境投資が行われるようになり， 公園や公共建造物，アメニティゾーンなどではオブジェクト自身の存在を強く主張する動きや変化のあるモニュ メントが造られるようになってきた。 これらのモニュメントの一つに古くから製作されてきた時鐘があり，ヨー ロッパのロイヤルアイスバウッ (Royal Eijsbouts) 社やプティ・アンド・フリッツェン(Petite\& Fritsen B.V.) 社の鐘 が日本でも多くみられる. 近年ではベルの振動音響特性についても解析的研究が実施されており ${ }^{(1)-(6)}$, ベルの固 有振動特性や音響放射特性が明らかにされつつある. 筆者らは図 1 に示寸ような任意の時刻に各種の音楽演奏を 行う自動演奏べルの基本周波数や高次周波数の調律のための FEM (有限要素法)解析に基づく内面形状決定法, そ れを基にした微小加工と計測を繰り返す調律加工法並びにコンピュータ制御の自動打鐘装置等を開発し, 自動演 奏ベルの音質改善とデザイン性向上に取組んできた. 自動演奏ベルでは基本周波数を平均律音階に調律した鐘の 組み合わせ (鐘列) を用いるので, 基本周波数の調律精度と高次周波数まで含めた音色が重要なポイントになる. 本報告では，鐘の形状パラメータと固有周波数の関係を検討するために有限要素法を適用した．試作したベルの 固有振動特性を十分な精度で解析できることを確認してから, 鐘形状の変化と基本周波数の変化の数值検討を行 い, 鐘の半径と肉厚で基本周波数が決定されることを明らかにした. 次に鐘の組み合わせとして, 肉厚と肉厚中 心線が同時に変化する相似形鐘列と定肉厚で肉厚中心線の形状を相似的に変化させていく定肉厚形鐘列の試作試

\footnotetext{
*原稿受付 2010 年 8 月 12 日

*1 正員，三菱重工業(株）（率160-0016＼cjkstart東京都港区港南 16-5）

*2 正員, 九州大学 工学研究院

*3 学生員, 九州大学 工学府

*4 正員, 九州大学 工学府

E-mail: usitokyo@gmail.com
} 
験を行い，鐘半径と固有周波数の関係を定量的に明らかにした．更に有限要素法を用いた逐次解析で高次周波数 を基本周波数の整数倍成分に調律するための形状決定法を提案し，その有効性を検証した．最後に鐘の振動が効 率よく音に変換されているかを確認するため, ベルの各モードについて境界要素法による音響放射解析を行った.

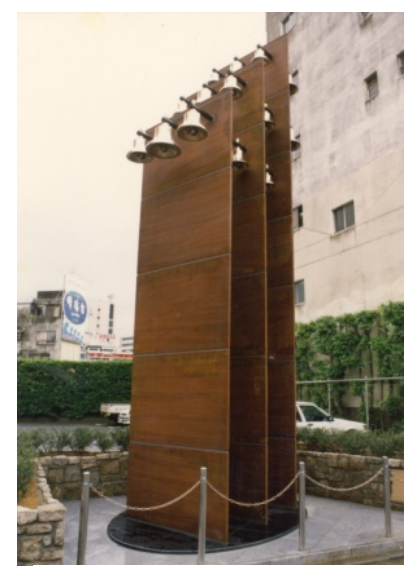

(a) Similar profile bell series

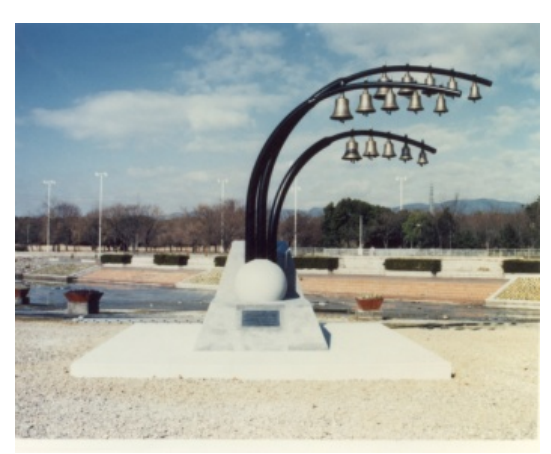

(b) Constant thickness bell series

Fig.1 Automatic performing bell

\section{2. 記号}

$A(\omega)$ : 鐘表面の振動加速度

$c$ : 音速

$E_{B}:$ 鐘材料の縦弹性係数

$f$ : 周波数

$\mathbf{H}$ : 影響係数行列

$L_{p}$ : 音圧レベル

$\mathrm{m}:$ 振動モードの円周方向の波数

$\mathrm{n}$ : 振動モードの軸方向節数

$V(\omega)$ : 鐘表面の振動速度

$<\mathrm{V}^{2}>$ : 空間二乗平均速度

$W$ : 音響放射パワー

$S:$ 鐘の表面積

$\Delta t:$ 鐘の肉厚変化

$T_{R}:$ 残響時間 $[\mathrm{sec}]$

$\eta:$ 損失係数

$\rho:$ 空気の密度

$\rho_{B}:$ 鐘材料の密度

$\sigma:$ 音響放射効率

$\omega$ : 角周波数

[ $]^{\mathrm{t}}$ : 転置行列

\section{3. 鐘の形状と振動音響特性}

\section{$3 \cdot 1$ 鐘の試作}

モニュメント等に用いられる鐘の場合は西洋鐘という一般的なイメージの制約の中でも外形のデザインはかな りの自由度が与えられるので, 本研究では各種の鐘の形状を調査し, 鐘として違和感のないような図 2 に示寸よ うな形状の鐘を試作した，素材は青銅（銅 78\%，すず $22 \%$ ）であり，鋳物を全面 NC加工して製作した. 


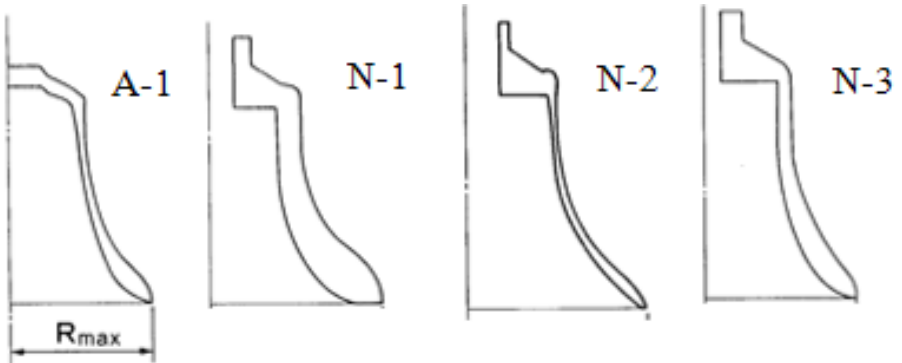

Fig.2 Bell profile

\section{$3 \cdot 2$ 鐘の固有振動数}

厚肉構造物である鐘の固有振動特性を有限要素法のソリッド要素を用いて解析する．鐘材料の密度と縦弹性係 数は鐘と同じ鋳造材料から切り出した試験片を用いて計測した次の值を用いた.

$$
\rho_{B}=8.35 \times 10^{3} \mathrm{~kg} / \mathrm{m}^{3}, \quad E_{B}=91.1 \mathrm{GPa}
$$

FEM 要素分割図を図 3 に，固有周波数と振動モードの解析結果を図 4 に示寸. 鐘の振動モードは周方向の波数 $\mathrm{m}$ と高さ方向の節数 $\mathrm{n}$ を用いて $(\mathrm{m}, \mathrm{n})$ モードと表示する. 鐘の最低次の周波数に相当する基本周波数は (2，0) モードであり，鐘の下端部が大きく変形する．有限要素法の計算精度を検証するために試作した鐘の振動計測を 実施した. 図 4 に固有周波数の計算結果との比較を示寸が，計算值は実測值と比較して $1 \%$ 以内の誤差に収まって いる.

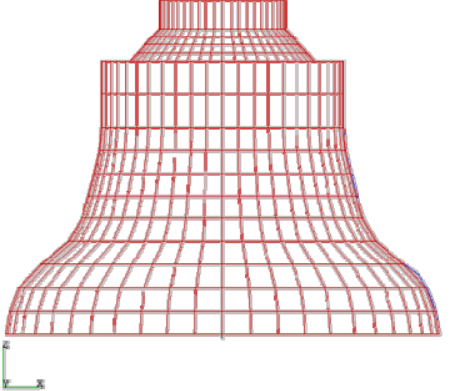

(a) Outer surface

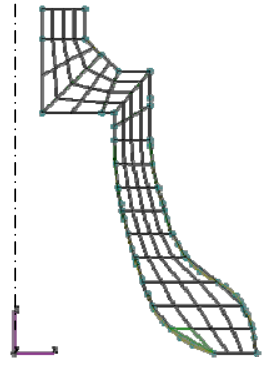

(b) Cross section

Fig.3 FEM mesh division of bell
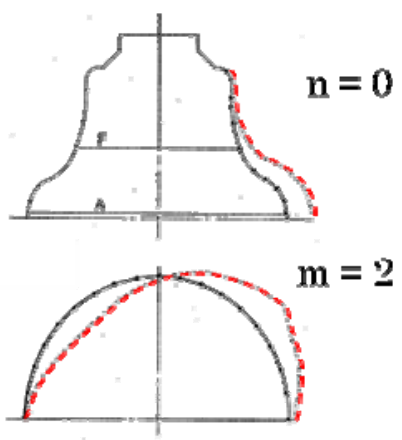

Calculated $1280 \mathrm{~Hz}$ Measured $1283 \mathrm{~Hz}$ (a) $(2,0)$ Mode

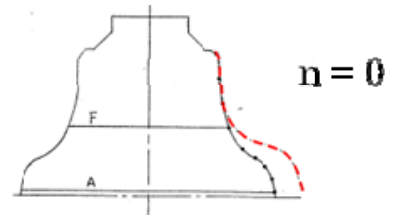

$\mathrm{m}=3$

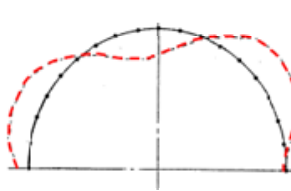

Calculated $2736 \mathrm{~Hz}$ Measured $2731 \mathrm{~Hz}$

(b) $(3,0)$ Mode

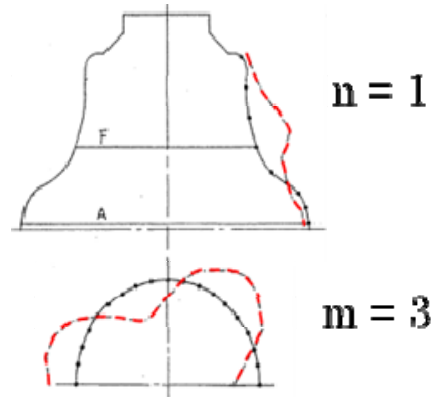

Calculated $4720 \mathrm{~Hz}$ Measured $4760 \mathrm{~Hz}$ (c) $(3,1)$ Mode

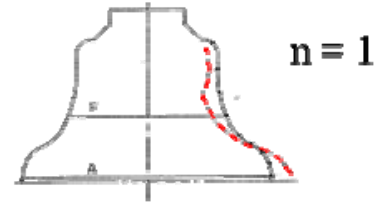

$m=2$

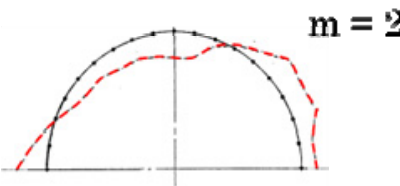

Calculated $6032 \mathrm{~Hz}$ Measured $6072 \mathrm{~Hz}$

(d) $(2,1)$ Mode

Fig.4 Mode shape and natural frequencies 


\section{$3 \cdot 3$ 固有モ一ドの残響時間}

鐘の振動音響設計では鐘の響き(残響)を支配する減衰の值を明らかにしておく必要があるので，各固有周波数 における残響時間を計測し式(1)で損失係数を決定した. 図 5 に各固有周波数における残響時間と損失係数の計測 結果を示す.

$$
n=\frac{\ln 10^{6}}{2 \pi f T_{R}}
$$
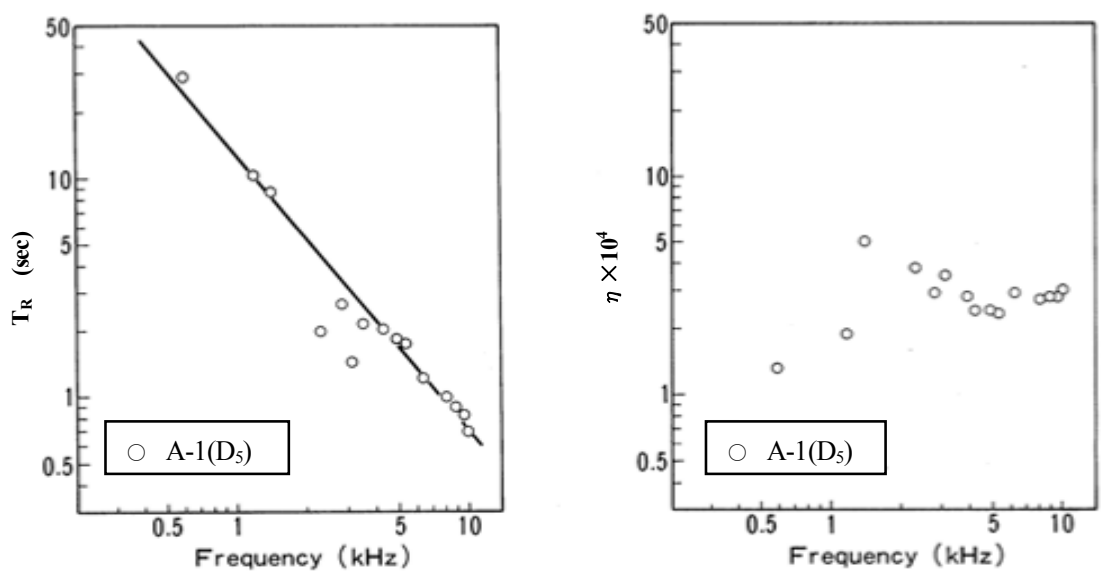

Fig.5 Measured reverberation time and damping

\section{$3 \cdot 4$ 鐘の形状と固有周波数}

各音階に対応したカリオン(組鐘)を製作する場合，鐘の数が 15 個以下の中小規模な施設では、鐘を取り付ける 構造体を含めた全体の美観的観点及びカリオンの演奏での音質の両面での統一性を維持するため、形状を相似に する相似鐘系列を用いることが多い(7)，一方、通常のメロディー演奏にコード演奏を加える場合などは 2 オク夕 一ブ程度(鐘の個数は 25 個)が必要であり, 相似鐘系列を用いると最大鐘径と最小鐘径の比が大きくなり, 自動演 奏のための桘打装置の格納等に問題が出てくる，そこで肉厚を一定として肉厚中心線だけを一定の比率で拡大も しくは縮小させる定肉厚形鐘列についても検討を行った．相似形鐘列と定肉厚形鐘列の基本周波数と鐘の半径の 関係を FEM 計算で検討した結果を図 6 に示す。

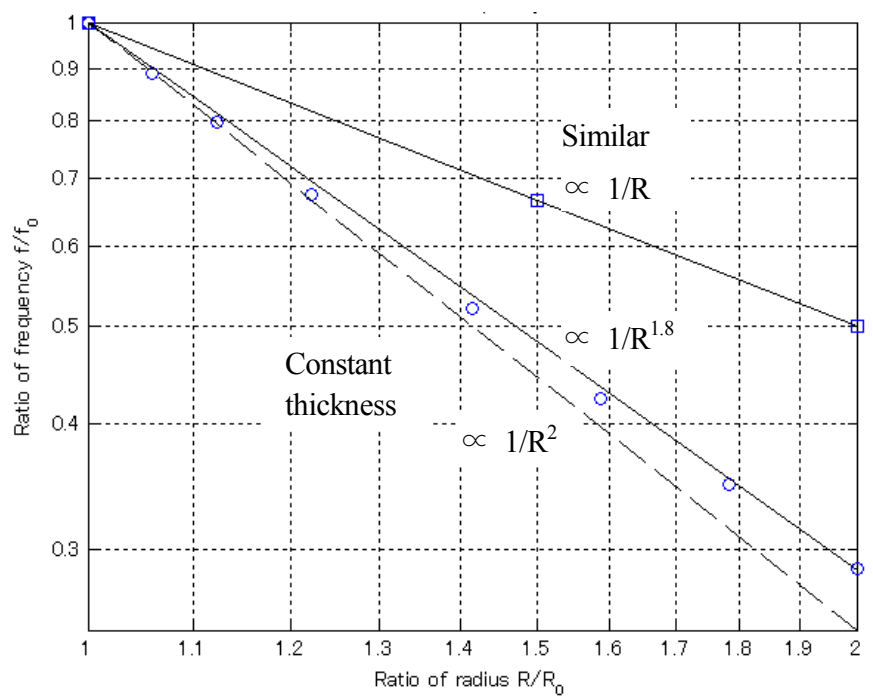

Fig.6 Calculated fundamental frequency and ratio of radius 
鐘の形状を相似形に変化させた相似形鐘列の基本周波数 $f$ は鐘の下端部の半径 $R$ と

$$
f \propto \frac{1}{R}
$$

の関係がある. また肉厚一定で肉厚中心線の形状を相似形に変化させた定肉厚形鐘列の基本周波数 $f$ は鐘の下端 の半径 $R$ と次の関係がある.

$$
f \propto \frac{1}{R^{1.8}} \sim \frac{1}{R^{2}}
$$

つまり，2 オクターブの鐘列を制作する場合，相似形鐘列では寸法比が 4 倍になるが，定肉厚形鐘列では 2 倍程 度で済むことになり，桘打装置の設置や鐘の音響放射面積の確保が容易になる.

\section{$3 \cdot 5$ 鐘の試作と基本周波数の調律}

図 6 の結果を検証するために，図 2 に示寸鐘形状の鐘を 10 個以上製作し基本周波数の計測を行った．図 7(a) に試作した相似形鐘系列鐘体 N-1, N-2 の基本周波数の計測結果を示す. 横軸には基本周波数のもつとも高い鐘 の下端最大半径 $R_{0}$ に対する半径比 $R / R_{0}$ ，縦軸には最も高い基本周波数 $f_{0}$ に対する周波数比 $f / f_{0}$ で表している. 図 7(a)では鋳物に残存するガス等による密度のわずかな違いや加工精度等の製作上のばらつきにより，式(3)の関 係からわずかにずれている．図 7(b)に鐘外形状に影響が無い様に鐘内径側の下端部を中心に数ミリ程度（肉厚の 10\%以下）の旋盤加工を行った後の基本周波数の計測結果を示している. 調律加工後は式(2)の関係が精度良く成 立している.

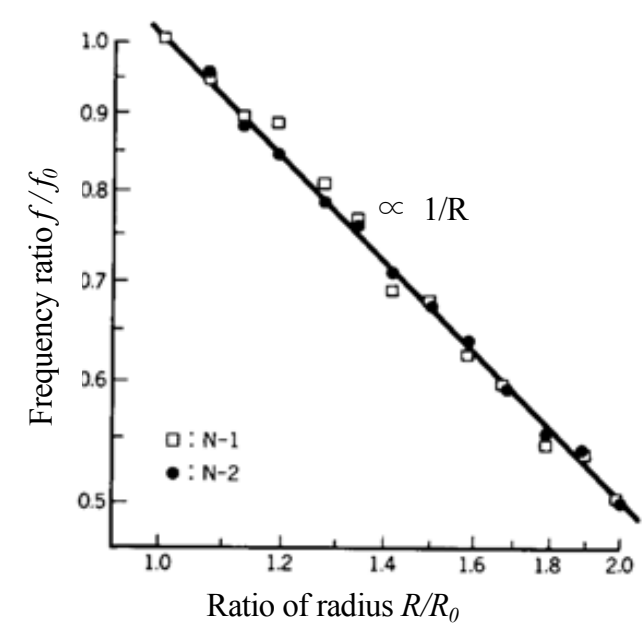

(a) Before tuning

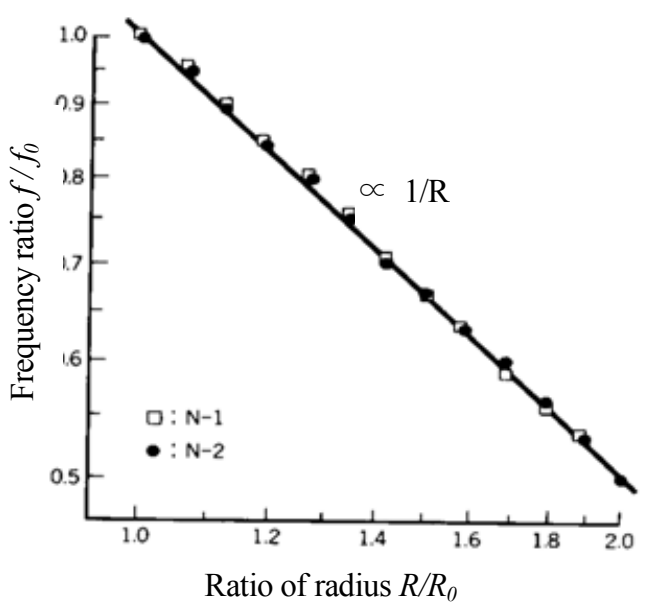

(b) After tuning

Fig.7 Measured fundamental frequency and radius ratio of similar bell

\section{$3 \cdot 6$ 調律誤差の許容值}

2 オクターブ分の鐘 25 個を一度に一つの鐘が打たれるメロディー演奏に用いる場合に，4名の視聴者に対して 聴感において調律誤差を感じないまで基本周波数の調律加工を行った例を図 8 に示寸．横軸は試作した各鐘の音 階を表しており, 縦軸は平均律音階の周波数に対する調律誤差を\%で表している. メロディー演奏における許容 調律誤差は約 $0.8 \%$ であった.

次に定肉厚形鐘列(N-3)15 個について, 同時に 2 個以上の鐘が打たれる和音演奏時に聴感上調律誤差を感じない まで調律加工を行った例を図 9 に示寸．和音演奏では聴感による鐘間の周波数比の比較が行われるため調律誤差 
に敏感となり，メロディー演奏時よりさらに精密な調律が必要となる。視聴者による評価では許容される和音演 奏時の調律誤差は約 $0.3 \%$ であった.

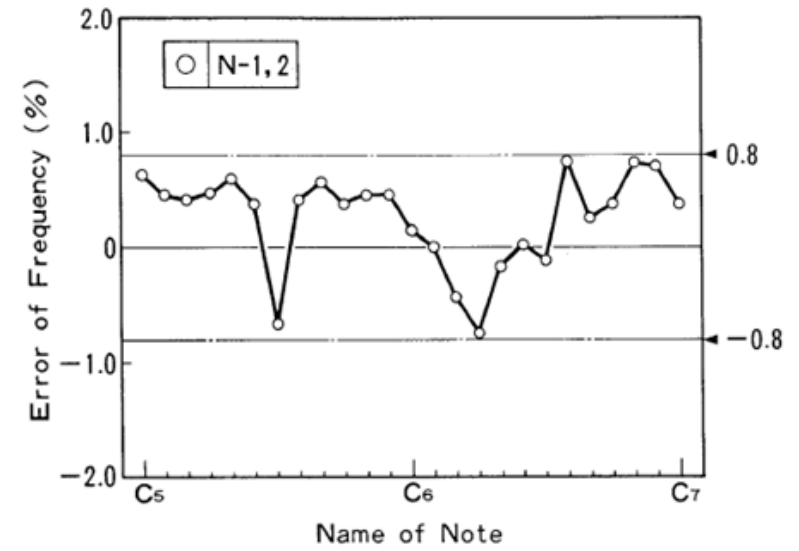

Fig.8 Allowable tuning error for playing melody

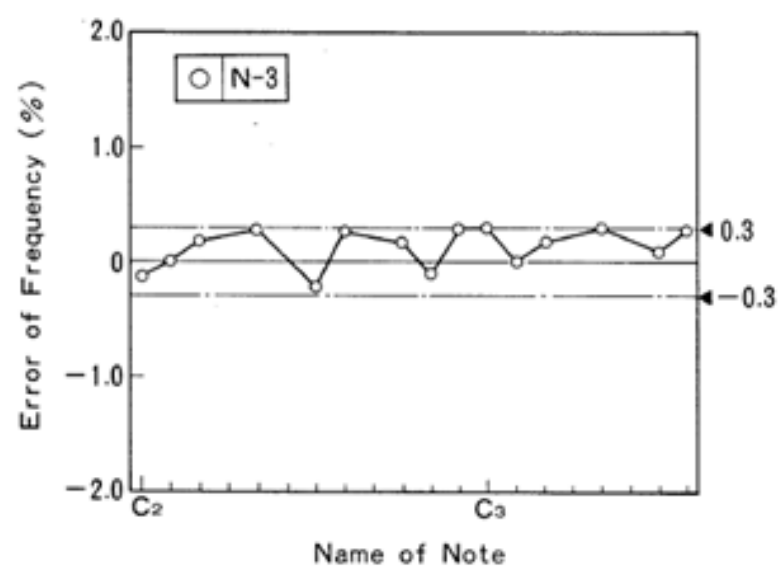

Fig.9 Allowable tuning error for playing chords

\section{4. 高次周波数成分の調律}

\section{$4 \cdot 1$ 高次周波数と残響時間の例}

良好な音質の鐘を実現するには, 高次周波数が基本周波数の整数倍になっていることが望ましい. 図 10 に槌打 時の鐘 A-1(音階 G4) の音の各周波数成分の時間経過を示寸. 横軸に各成分の周波数, 縦軸にその音圧レベル $L p$, 2 つの横軸は残響時間 $T_{R}$ と周波数を表している. 図 10 に示寸ように 3 次以上の高次モードの音圧レベルの減衰 が 1 次, 2 次の低次モードの減衰に比べて早い. 1 次, 2 次の低次モードの周波数成分は緩やかに減衰しているこ とから，鐘の音質は 1 次， 2 次の低次モードの周波数成分に支配されていることが分かる. そこで自動演奏ベル の高次周波数の調律の方針として， 2 次モードの周波数を基本周波数の 2 倍とし，その上の高次周波数をできる だけ基本周波数の倍音になるように形状を決定することにする.

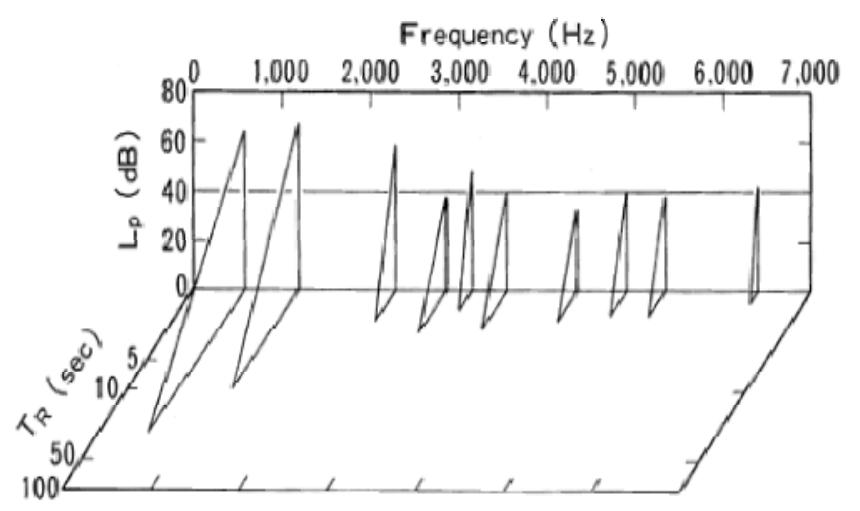

Fig.10 Frequency spectrum and reverberation time of bell sound

\section{$4 \cdot 2$ 内面切削による固有周波数の変化}

鐘の外面形状は変化させずに，内面の形状変更だけで基本周波数，高次周波数を調律することを考える．図 3 に示す FEM モデルを用いて, 鐘内径側の形状を変化させた場合の各振動モードの周波数の変化を計算する. 内 面の第 $\mathrm{i}$ 節点を $\Delta t_{\mathrm{i}, 0}$ だけ径方向に変化させた場合の, 第 $\mathrm{s}$ 次固有周波数の変化分を $\Delta f_{\mathrm{s}} \mathrm{i}$ とおく. 形状変更前の 第 $\mathrm{s}$ 次固有周波数を $f_{s}$, 目標と寸る第 $\mathrm{s}$ 次固有周波数を $f^{\prime}{ }_{\mathrm{s}}$ とおき, 目標周波数を達成するために内面の節点を

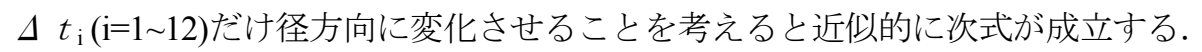




$$
\left[\begin{array}{c}
f_{1}^{,}-f_{1} \\
\vdots \\
f_{s}^{,}-f_{s}
\end{array}\right]=\left[\begin{array}{cccc}
\frac{\Delta f_{11}}{\Delta t_{1,0}} & \frac{\Delta f_{12}}{\Delta t_{2,0}} & \cdots & \frac{\Delta f_{112}}{\Delta t_{12,0}} \\
\frac{\Delta f_{s 1}}{\Delta t_{1,0}} & \frac{\Delta f_{s 2}}{\Delta t_{2,0}} & \cdots & \frac{\Delta f_{s 12}}{\Delta t_{12,0}}
\end{array}\right]\left[\begin{array}{c}
\Delta t_{1} \\
\Delta t_{2} \\
\vdots \\
\Delta t_{12}
\end{array}\right]
$$

$$
\Delta \mathbf{f}=\mathbf{H} \Delta \mathbf{t}
$$

ただし

$$
\Delta \mathbf{f}=\left(\begin{array}{c}
f_{1},-f_{1} \\
\cdots \\
f_{s},-f_{s}
\end{array}\right), \mathbf{H}=\left[\begin{array}{ccc}
\frac{\Delta f_{1,1}}{\Delta t_{1,0}} & \cdots & \frac{\Delta f_{1,12}}{\Delta t_{12,0}} \\
\vdots & \cdots & \vdots \\
\frac{\Delta f_{s 1}}{\Delta t_{1,0}} & \cdots & \frac{\Delta f_{s, 12}}{\Delta t_{12,0}}
\end{array}\right], \Delta \mathbf{t}=\left(\begin{array}{c}
\Delta t_{1} \\
\vdots \\
\Delta t_{12}
\end{array}\right)
$$

図11(a)に示すように，内面の節点を 1 要素分だけ径方向に変化させてリング状に切削した場合の固有周波数の 変化を, 内面の下から 12 節点分だけ計算した. 図 11(b)に内面の切削位置と固有周波数の変化を示す. 横軸は各 振動モードの切削前の周波数を基準としたときの切削前後の周波数変化を\% で示している. 一方，縦軸は切込み を入れた節点の高さ方向の位置を表している.これらの值は影響係数行列 $\mathbf{H}$ の各要素に対応する.

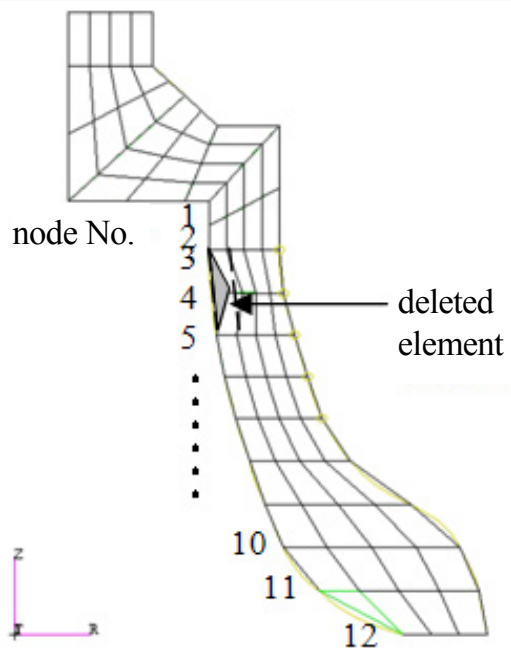

(a) Change of FEM mesh division

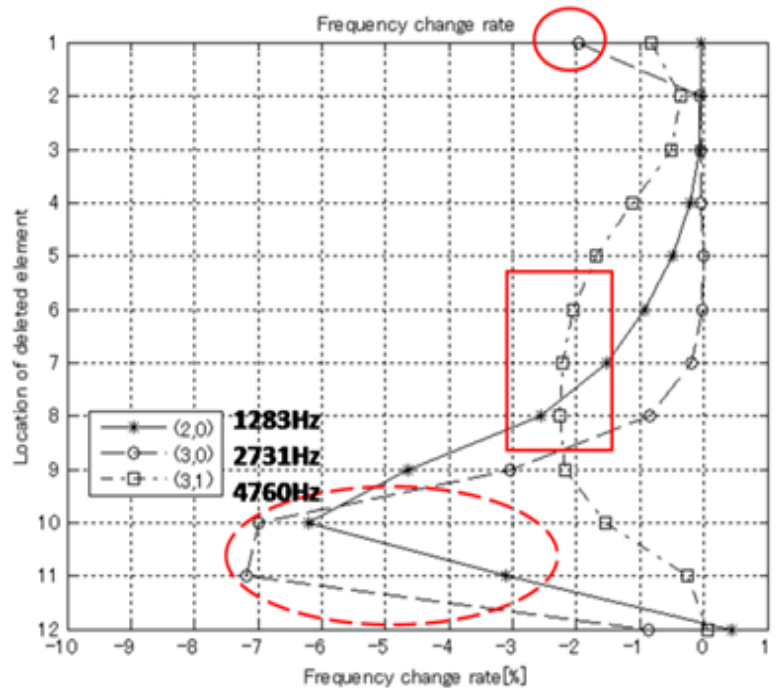

(b) Location of thickness change and frequency variation

Fig.11 Frequency change due to the decrease of inner

\section{(1) 最小二乗法の適用 ${ }^{(8)}$}

次の二乗誤差を最小にする板厚変化量 $\Delta t_{i}$ を決定する.

$$
\delta=|\Delta \mathbf{f}-\mathbf{H} \Delta \mathbf{t}|^{2}=(\Delta \mathbf{f}-\mathbf{H} \Delta \mathbf{t})^{t}(\Delta \mathbf{f}-\mathbf{H} \Delta \mathbf{t})
$$

誤差 $\delta$ が最小になる条件は 


$$
\frac{\partial \delta}{\partial \Delta t_{i}}=0, \quad i=1 \sim 12
$$

\section{$\mathbf{H}^{t} \mathbf{H} \Delta \mathbf{t}=\mathbf{H}^{t} \Delta \mathbf{f}$}

目標とする $\mathrm{s}$ 個の固有周波数に対して, 板厚パラメータ $\Delta t_{\mathrm{i}}$ が 12 個変更可能であり, $\left(\mathbf{H}^{t} \mathbf{H}\right)^{-1}$ が存在すれば, 最適設計変更パラメータ $\Delta \mathbf{t}$ を決定することができる. 図 3 に示すべルの基本周波数である $(2,0)$ モー゙の固有周 波数の目標值を $\mathrm{f}_{1}{ }^{\prime}=1244.51(\mathrm{~Hz})$ ( $\mathrm{D}_{6}$ \#の音), $(3,0)$ モードの周波数を 2 倍音 $\mathrm{f}_{2}{ }^{{ }^{\prime}},(3,1)$ モードの周波数を 4 倍音 $\mathrm{f}_{4}{ }^{\prime}$ に 調律することを試みる. 図 12 に 2 回の繰り返し計算で目標固有周波数に $0.5 \%$ 以内の計算詔差で収束していく状 況を示す．また図 13 に 2 回目の修正後の内面形状を示している.

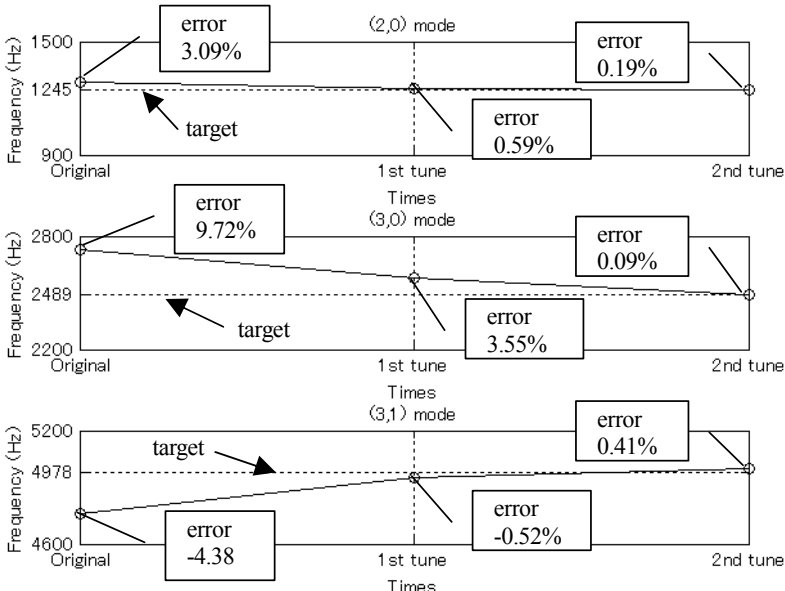

Fig.12 Tuned natural frequencies of $(2,0),(3,0),(3,1)$ mode

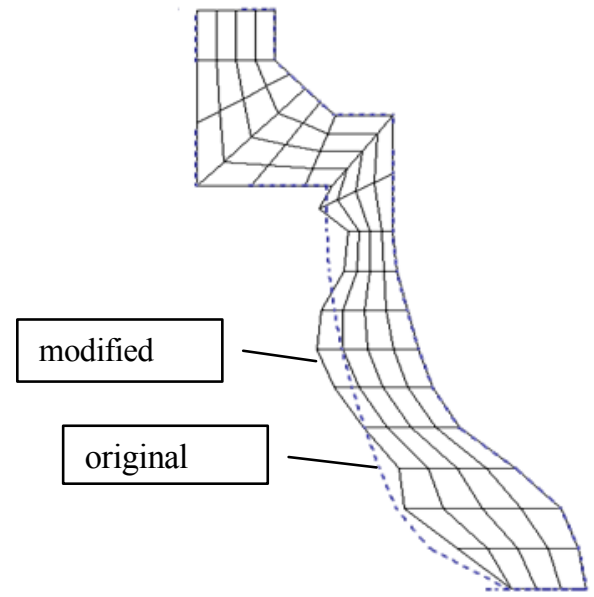

Fig.13 Bell profile after tuning

\section{（2）簡便法の適用}

図 11(b)に示すように，基本周波数の(2,0)モード，基本周波数の 2 倍近くの周波数を有する(3,0)モード，4 倍近

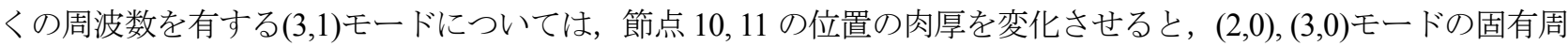

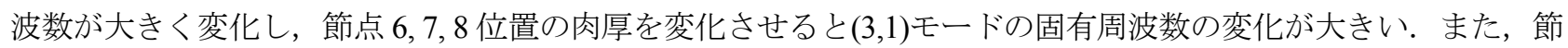

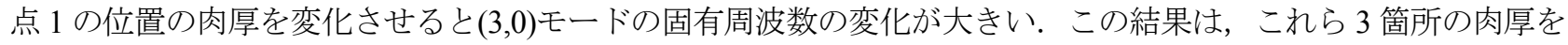
変更することで 3 つ固有周波数を調整できる可能性を示している.

そこで前節と同様に基本周波数である(2,0)モードの固有周波数の目標值を $\mathrm{f}_{1}{ }^{\prime}=1244.51(\mathrm{~Hz}) \quad\left(\mathrm{D}_{6} \#\right.$ \#音)，(3,0) モードの周波数を 2 倍音 $\mathrm{f}_{2}{ }^{\prime},(3,1)$ モードの周波数を 4 倍音 $\mathrm{f}_{4}{ }^{\prime}$ に調律することを試みる. 節点 1 の変化量を $\Delta \mathrm{t}_{\mathrm{a}}{ }^{2}$, 節点 $6,7,8$ の変化量を等しく $\Delta \mathrm{t}_{\mathrm{b}}$, 節点 10,11 の変化量を等しく $\Delta \mathrm{t}_{\mathrm{c}}$ とおくと, 式(5)は次の $3 \times 3$ の正方行列 となり肉厚変更量を決定することができる.

$$
\left[\begin{array}{l}
f_{1}-f_{1} \\
f_{2}-f_{2} \\
f_{4}-f_{4}
\end{array}\right]=\left[\begin{array}{cccc}
\frac{\Delta f_{11}}{\Delta t_{1,0}} & \sum_{n=6}^{8} \frac{\Delta f_{1 n}}{\Delta t_{n, 0}} & \sum_{n=10}^{11} \frac{\Delta f_{1 n}}{\Delta t_{n, 0}} \\
\frac{\Delta f_{21}}{\Delta t_{1,0}} & \sum_{n=6}^{8} \frac{\Delta f_{2 n}}{\Delta t_{n, 0}} & \sum_{n=10}^{11} \frac{\Delta f_{2 n}}{\Delta t_{n, 0}} \\
\frac{\Delta f_{21}}{\Delta t_{1,0}} & \sum_{n=6}^{8} \frac{\Delta f_{3 n}}{\Delta t_{n, 0}} & \sum_{n=10}^{11} \frac{\Delta f_{3 n}}{\Delta t_{n, 0}}
\end{array}\right]\left[\begin{array}{l}
\Delta t_{a} \\
\Delta t_{b} \\
\Delta t_{c}
\end{array}\right]
$$


ただし, 肉厚変更後の固有振動数は $\mathrm{f}_{1}, \mathrm{f}_{2}, \mathrm{f}_{4}$ と厳密には一致しないので, 構造変更後の值を用いて再度固有値解 析を行い,変更後の固有振動数を確認寸る. その結果が目標值に到達していなければ, 変更後の形状を用いて, 式 (9)の計算を繰り返す. 図 14 に(2,0), (3,0), (3,1)モードの周波数の第 1 ステップ, 第 2 ステップにおける調律結果を 示寸. 第 2 ステップまでの計算で，目標周波数に対する誤差が $0.5 \%$ 以内に収まっている. 図 15 に第 2 ステップ 調律後のベルの断面形状を示寸，点線が調律前の形状，実線が調律後の新形状(要素分割図)に対応しており，下 端部を減肉して中央部を増肉し，上端部を若干増肉した構造になっている．実際の加工においては，計算で得ら れた形状の増肉部の厚みを持った鐘を製作し, 内面の切削を段階的に行いながら, 周波数を調律していった.

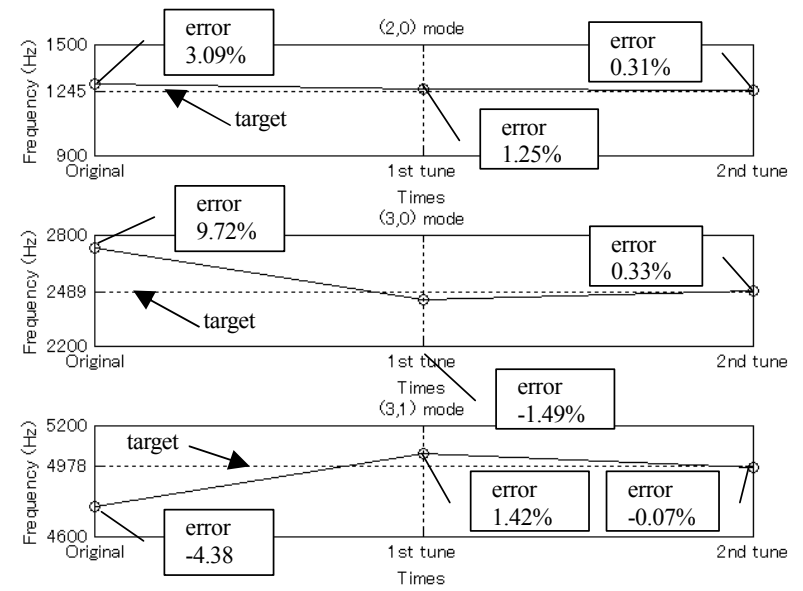

Fig.14 Tuned natural frequencies of $(2,0),(3,0),(3,1)$ mode

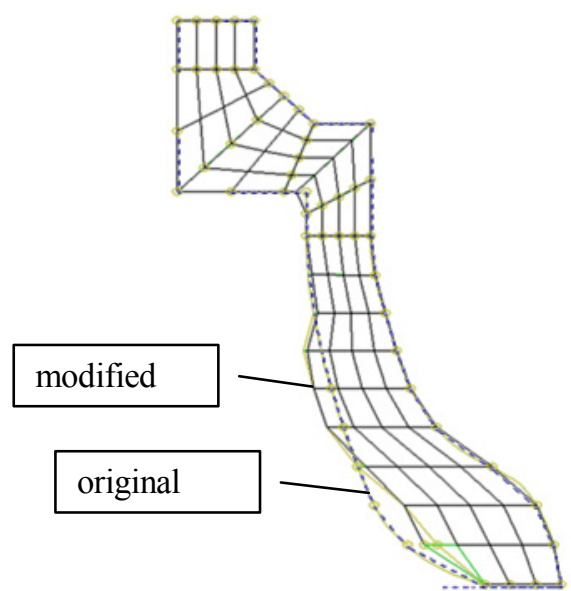

Fig.15 Bell profile after tuning

\section{5. 鐘の振動による音響放射特性}

\section{$5 \cdot 1$ 鐘の振動による放射音圧}

図 16 に振動による放射音圧を解析するための境界要素法(BEM)解析モデルを示す．鐘の外面と内面を約 4000 個の境界要素に分割し, 各固有振動モードに対応する加速度分布を要素に与えて要素上に発生する音圧を求めた. 要素内では圧力は一定と仮定し, 鐘の内側と外側の間の音場の内部共振を抑えるため, 内部の点を強制的に零と する式を付け加える CHIEF Method を用いた. 計算方法の詳細は文献(9),(10)に示す. 図 17 に(2,0)モードの共 振点における，鐘の下面から $110 \mathrm{~mm}$ の高さのベル表面における音圧分布の計算結果と表面近接音の計測結果を 示す. 音圧の周方向分布は(2,0)モードに対応している. 音圧の計測は計算条件に対応する無響室ではなく, 反射 のある実験室で行っており厳密な比較はできないが，計算結果とは概略一致している．

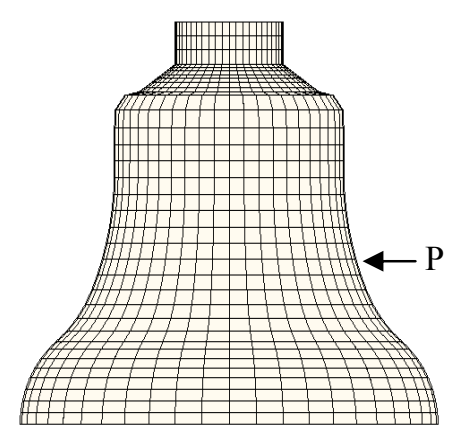

Fig.16 BEM model of bell and measuring point of SPL

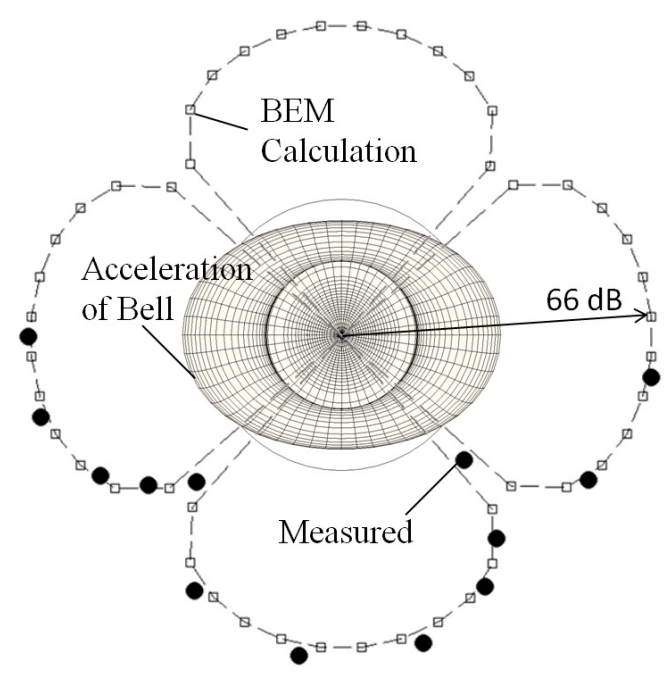

Fig. 17 Calculated and measured SPL of $(2,0)$ mode 


\section{$5 \cdot 2$ 固有モ一ドの音響放射効率}

振動で音を放射する鐘の場合，振動が効率よく音に変換される必要がある．次式で示される音響放射効率 $\sigma$ は 振動が音に変換される割合を示寸ものであり，鐘の各固有周波数において $\sigma \geqq 1$ が望ましい. 図 16 に示す BEM モデルで各節点に固有振動モードに対応する加速度分布 $A(\omega)$ を与えて, 鐘の表面に発生する音圧 $p(\omega)$ を求め, それを用いて次式で角周波数 $\omega$ における音響放射パワー $W$ 及び音響放射効率 $\sigma$ を計算した.

$$
W=\int_{S} p\left\{\frac{1}{j \omega} A(\omega)\right\}^{*} d S, \quad \sigma=\frac{W}{\rho c<V^{2}>S}
$$

図 18 に角周波数 $\omega$ を変化させて固有モードの音響放射効率 $\sigma$ を計算した結果を示寸. $(2,1),(3,0),(3,1)$ モードの 共振点における音響放射効率は 1.0 程度になっており, 鐘が打撃されて固有振動モードが励起された場合, 振動 が音に効率よく変換されている.

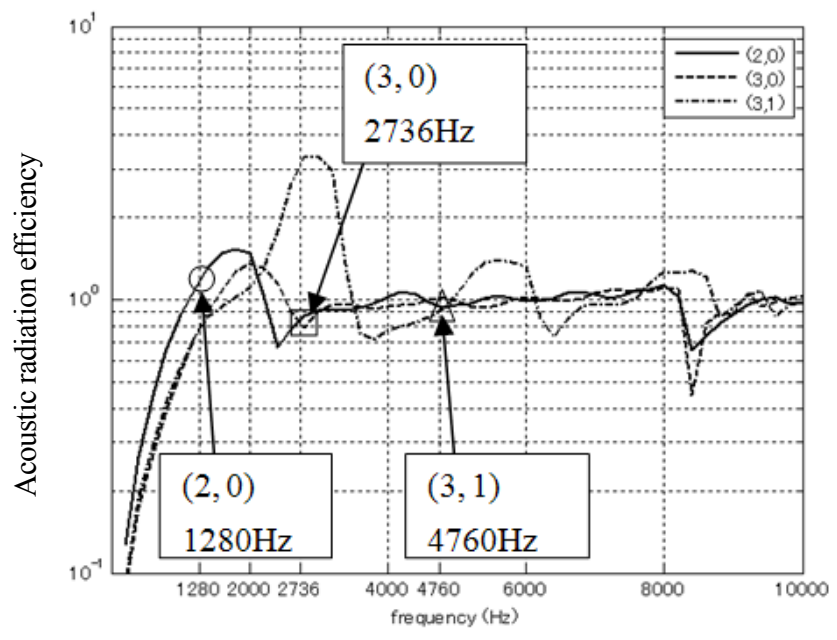

Fig.18 Calculated acoustic radiation efficiencies

\section{6. むすび}

自動演奏ベルに用いる鐘としては種々の断面形状が考えられるが，基本周波数を効率的に精度よく設計するには 相似形鐘系列及び定肉厚形鐘系列を採用することが有効である. 特に定肉厚形鐘系列は鐘外径を大きく変化させ ることなく広带域にわたる音階を得ることができる. 自動演奏ベルの音階を決定する基本周波数に要求される調 律誤差はメロディー演奏で約 $0.8 \%$ 以内, 和音演奏で約 $0.3 \%$ 以内であることを聴感試験で明らかにした. さらに, FEM 解析をべースとする基本周波数及び高次モード周波数の調律手法について検討を行い, 内面形状を変化させ ることで高次周波数まで調律可能であることを確認できた. また, BEM を用いて鐘の振動による放射音解析を行 い, 鐘の各共振周波数では音響放射効率がほぼ 1.0 であり, 振動が効率よく音に変換されていることを検証した. 今後は鐘の内外面からの音響放射パワーの差異や槌打装置の岡性の影響が鐘の音に及ぼす影響等を検討するとと もに，周囲の境界条件と鐘の音の伝搬の関係についても検討していく予定である.

\section{文献}

(1) A. Lehr, Partial Groups in the Bell Sound, Journal of the Acoustical Society of America, Vol.79, No.6, (1986)

(2) R. Perrin, T. Charnley, J. dePOnt, Normal Modes of Modern English Church Bell, Journal of Sound and Vibration, Vol.90, No.1 (1983)

(3) Thomas D Rossing, The Acoustics of Bells, American Scientist, 72(1984) 
(4) H. Nichols, Vibration Modes of a Tuned Handbell, Journal of the Acoustical Society of America, Vo.76, No.4 (1984)

(5) D Rossing, H Sathoff, Modes of Vibration and Sound Radiation from Tuned Handbells, Journal of the Acoustical Society of America, 68(6) (1980)

(6) 河野俊一, 斎藤峻, 板谷芳樹, 増村徹, “ベルの振動・音響解析”, 日本音響学会騒音・振動研究会資料, $N-94-42$ (1994)

（7）上野大司，入江良彦，高木茂，太田和秀，“自動演奏ベルの音響特性解析”，日本音響学会騒音・振動研究 会資料，，N-90-295 (1990)

(8) 畔上秀幸, “形状最適化問題の解法” ，計算工学，Vol.2, No4 (1997), pp. 239-247

（9）中村任男，太田和秀，入江良彦，本田巌，石川秀之，“クランクケースの振動・音響特性解析法”，日本舶 用機関学会誌，Vo.24, No.12 (1989), pp. 578-582

(10) 太田和秀，金瑢洙，“エンジンブロックの振動放射音特性について”，日本機械学会，Dynamic and Design Conference (2007) 